\title{
Prevalence of bovine
}

\section{tuberculosis in dairy cattle and the associated risk factors in}

\section{Oromia, Ethiopia}

\author{
Dereje Lemu*, Abeje Abera, Tadelech kebede and \\ Dimshasha Tolera
}

Department of Microbiology, Asella Regional Veterinary Laboratory, Asella, Ethiopia

Received: 21 November, 2019

Accepted: 29 January, 2020

Published: 31 January, 2020

*Corresponding author: Dr. Dereje Lemu, Department of Microbiology, Asella Regional Veterinary Laboratory, Asella, Ethiopia, Tel: +251921421593;

E-mail: Dereje_lemu@yahoo.com

Keywords: Bovine tuberculosis; Dairy cattle; Risk factors; Prevalence; Comparative intradermal tuberculin test

ORCiD: https://orcid.org/0000-0002-1745-7061

https://www. peertechz.com

Check for updates

\begin{abstract}
A cross-sectional study was conducted in February 2013 by using Comparative Intra-dermal Tuberculin Test (CIDT) in order to determine the prevalence bovine TB and the associated risk factors in Tiyo, Agarfa districts and in Shashemene town of Oromia National Regional State. The study subjects included were crossbred dairy animals, kept under intensive e management systems. A standard questionnaire formats was used to collect information relevant to the age, body condition and the herd size of the animals. Five hundred forty two dairy animals were included in the study. The individual prevalence of BTB was $4.24 \%$ and $20.66 \%$ at $\geq 4 \mathrm{~mm}$ and $\geq 2 \mathrm{~mm}$ cut off value respectively. The herd level prevalence of was found to be $48.9 \%$ ( $95 \%$, Cl: $34 \%-63 \%)$. The questionnaires survey results of this study indicated that, more than $85.1 \%$ of the households were consuming raw milk, whereas $14.8 \%$ were consuming heat-treated milk. $74.4 \%$ of the respondents were aware, that the transmission of bovine TB through consumption of raw milk, milk products and raw meat. The present study revealed that the overall low prevalence of bovine TB in the study area. Education and raising awareness of the animal owners about the health risks of contacting with infected animals, consumption habits of raw meat, unpasteurized milk, and milk products are very imperative. Moreover, appropriate diagnosis of the disease and provision of useful information for use by public health and agricultural officials is important in the control practices of bovine tuberculosis. This approach is highly appreciated and is a key to tackling zoonotic tuberculosis for the future.
\end{abstract}

\section{Introduction}

Bovine Tuberculosis (BTB) was widespread in many European countries and is a public health concern in some developing countries [1]. It is a chronic bacterial disease of animals, wildlife and humans and is caused by Mycobacterium bovis (M.bovis), which belongs to a group of mycobacteria known as Mycobacterium tuberculosis complex (MTBC) [2-4]. M. bovis has one of the broadest host ranges of all known pathogens and has been diagnosed worldwide [5].

Bovine tuberculosis is usually characterized by formation of nodular granulomas known as tubercles and they are most frequently observed in several tissues, even though they are frequently seen in lymph nodes at head and neck, lung, intestines, liver and pleural cavity. Extreme emaciation and acute respiratory distress may occur during the terminal stages of the disease [6]. The Rates of M.bovis infection is higher among closely confined animals than animals in extensive farming systems [7]. This disease is one of the seven most neglected endemic diseases in the world, particularly in developing countries [8] and is a significant zoonosis that can spread to humans through aerosols, by the consumption of unpasteurized milk and dairy products and through meat from infected cows [7,9]. Veterinarians, farmers, and abattoir workers were most considered at the risk of this disease. The disease induces high animal morbidity and mortality that eventually reduces the financial capital and increases production costs [10]. As an OIE List B disease, it is one of the significant diseases, which affect the international trade of animals and animal products between countries [11].

Bovine $\mathrm{Tb}$ is widespread in many countries. During 2015 to 2016, 179 countries and territories reported their status concerning bovine TB to OIE. Of these, more than half reported the presence of the disease in livestock and wildlife, demonstrating its wide geographical spread. In 2016, there were almost 1.7million deaths from tuberculosis and 
10.4million new infections overall, according to the WHO's 2017 Global tuberculosis report [12]. The zoonotic transmission of $\mathrm{M}$. bovis is responsible for $10 \%-15 \%$ of new human TB cases in developing countries [12]. This disease has been eradicated in most parts of the developed countries, but remains prevalent in many parts of sub-Saharan African countries. The studies in Ethiopia suggested that this disease is endemic and its prevalence varies depending on the animal husbandry systems. The prevalence ranges from $3.5 \%-50 \%$ was reported by many authors [13-20]. To our knowledge, information on bovine TB among dairy herds in the study area is limited.

Therefore, the current study was designed to investigate the epidemiology of bovine TB and to assess the animal level and herd level risk factors of BTB.

\section{Materials and methods}

\section{Study area}

The study was conducted in Tiyo and Agarfa districts and Shashemene town of Oromia National Regional State respectively. The area is located between 038046.17 to 0390 $52.153 \mathrm{E}$ and 07018.814 to $07056.911 \mathrm{~N}$. The altitude ranges from 2108-2406 meters above sea level. The minimum and maximum temperature and the related humidity ranges from $8.4^{\circ} \mathrm{C}-22.6^{\circ} \mathrm{C}$ and $43 \%$ to $60 \%$ respectively. The average rainfall is $1600-2000 \mathrm{smm}$. The study dairy herds were managed under intensive management system and they were kept indoors.

\section{Study design, study population and Sample size deter- mination}

A cross-sectional study was conducted in February 2013 by using Comparative Intra-dermal Tuberculin Test (CIDT) in order to determine the prevalence bovine TB. The tuberculin test is the internationally accepted standard for detection of infection with $M$. bovis. This test was conducted according to the procedures described by [21]. The study subjects included crossbred dairy animals. Caves younger than six months of age, late pregnant cows and clinically sick animals were not included in the study. The late pregnancy of each cow was determined from the information from the owners and farm records. The herd size of the animals was categorized in to small size (less than seven animals), medium size (8-15 animals), and large size (above 16 animals). The sample size was determined according to formula given by Thrusfield [22], for simple random sampling methods using an expected prevalence of $50 \%$ at $95 \%$ level of confidence and $5 \%$ desired precision. However, the sample size was increased to 542 in order to increase the precision.

\section{Questionnaire survey}

The semi-structured questionnaire was used to collect information the general status of the farm, the management system and the raw milk consumption of the respondents were registered. The questionnaire was pre-tested before implementation at the field level.

\section{Data collection and analyses}

A standard questionnaire format was used to collect information relevant to the age of the animals, their body condition and the size of the herd. The ages of the animals were determined based on dentition formula according to [23]. The stage of pregnancy was determined based on information from owners and farm records. The body condition scoring was done according to the established guidelines of [24]. The data were stored in Microsoft Excel spread sheet and analyzed by using STATA version 12 [25]. The Chi-square test (X2) was used to evaluate the association between the risk factors and the tuberculin positive reactivity. 95 percent confidence interval (CI) was calculated and its statistical significance was assumed, if the confidence interval did not include one among its values. In all the analyses comparisons having the $(P<0.05)$ were considered as statistically significant.

\section{Results}

The individual level prevalence based on comparative intradermal tuberculin test were $4.24 \%$ and $20.66 \%$ at $\geq 4 \mathrm{~mm}$ and $\geq 2 \mathrm{~mm}$ cut off value respectively. The herd level prevalence was $48.9 \%$ (Table 1 ). The result of this study revealed that, there is no statistically significant association between the tuberculin test positivity and the assessed risk factors such as towns, age, herd size and body condition (Table 2 ).

Table 1: The individual animal and herd level prevalence of tuberculin reactors.

\begin{tabular}{|c|c|c|c|c|}
\hline Variable & Negative & Positive & $\begin{array}{c}\text { Prevalence at } \mathbf{4} \mathbf{m m} \\
\text { cut off }\end{array}$ & $\begin{array}{c}\text { Prevalence at } \geq \mathbf{2 m m} \\
\text { cut off }\end{array}$ \\
\hline $\begin{array}{c}\text { Individual } \\
\text { animal }\end{array}$ & 542 & 23 & $4.24 \%$ & - \\
\hline $\begin{array}{c}\text { Individual } \\
\text { animal }\end{array}$ & 453 & 118 & - & $20.66 \%$ \\
\hline Herd & 47 & 23 & $48.9 \%$ & - \\
\hline
\end{tabular}

Table 2: The risk factors and their associations with the prevalence of tuberculin intra-dermal test.

\begin{tabular}{|c|c|c|c|c|c|c|}
\hline Variable & Catagories & No tested & Positive & Prevalence & $\mathbf{X}^{2}$ & P-value \\
\hline Town & Tiyo & 243 & 9 & $3.7 \%$ & & \\
\hline & Agarfa & 88 & 1 & $1.1 \%$ & 3.166 & 0.205 \\
\hline & Shashemene & 211 & 13 & $6.16 \%$ & & \\
\hline Total & Female & 542 & 23 & $4.24 \%$ & & \\
\hline Age (Years) & $<2$ & 150 & 5 & $3.33 \%$ & & \\
\hline & $2-5$ & 365 & 17 & $4.65 \%$ & 0.278 & 0.870 \\
\hline & $>5$ & 27 & 1 & $3.7 \%$ & & \\
\hline Herd size & $<7$ & 111 & 5 & $4.5 \%$ & 0.155 & 0.925 \\
\hline & $8-15$ & 190 & 8 & $4.21 \%$ & & \\
\hline & $>16$ & 241 & 10 & $4.14 \%$ & & \\
\hline BCS & Thin & 101 & 2 & $1.98 \%$ & 1.517 & 0.468 \\
\hline & Medium & 387 & 18 & $4.65 \%$ & & \\
\hline & Good & 54 & 3 & $5.5 \%$ & & \\
\hline
\end{tabular}

\section{Discussions}

The study result revealed that the CIDT prevalence of $4.02 \%$ and $20.66 \%$ at $\geq 4 \mathrm{~mm}$ and $\geq 2 \mathrm{~mm}$ cut off value at individual animal level respectively and the herd level CIDT prevalence 
was $48.9 \%$. This result is higher than the prevalence of $1 \%$ at the cutoff off value $\geq 4 \mathrm{~mm}$ and $4.02 \%$ at the cut off value $\geq 2$ in Ambo and Toke districts in Ethiopia [26]. The higher prevalence of tuberculin test positivity of $13.9 \%$ and $15.8 \%$ was also reported in Tigray and Arsi respectively $[27,18]$.

In the present study, the highest prevalence was recorded in Shashemene town, which is $6.16 \%$ when compared to Tiyo $3.7 \%$ and Agarfa $1.1 \%$ districts. The highest prevalence of tuberculin positive reactivity was $4.65 \%$ in age group between 2-5 years as compared to the younger and older age group. The prevalence of small and medium herd size is similar, which is $4.25 \%$ and $4.21 \%$, as compared to the large herd size, which is $4.14 \%$. The animals with good body condition score have the highest prevalence $5.5 \%$ of tuberculin positive reactivity (Table 2).

The current study revealed the herd level CIDT prevalence was $48.9 \%$. The result of the current study revealed that, there is no statistically significant associations between the tuberculin test positivity and the assessed risk factors such as towns, age, herd size and body condition $(P>0.05)$.

The questionnaires result of this study indicated that, more than $85.1 \%$ of the households consumed raw milk, while $14.8 \%$ were consumed heat- treated milk. $74.4 \%$ of the respondents were aware that the bovine TB could be transmitted through consumption of raw milk, milk products and raw meat. The public health importance of $M$. bovis infection was reported mainly by consumption of infected milks [28-32]. Bovine Tuberculosis (BTB) is a public health concern in some developing countries and results in trade barriers, as well as posing a risk to food safety and human health [12].

\section{Conclusions}

The present study revealed overall low prevalence of bovine TB in the study area. In detail, information on molecular characteristics of $M$. bovis, strain affecting the cattle population in Ethiopia, is limited. Thus, it is suggested that, the isolation, identification and molecular diagnosis of different strains of M. bovis need to be further investigated in the study area in a way of multidisciplinary approach. Education and raising awareness of the animal owners about the health risks of contacting with infected animals, consumption habits of raw meat, unpasteurized milk, and milk products is very imperative.

Moreover, appropriate diagnosis of the disease and provision of useful information for use by public health and agricultural officials is important in the control practices of bovine tuberculosis. This approach is highly appreciated and is a key to tackling zoonotic tuberculosis for the future.

\section{References}

1. Michel AL, Muller B, van Helden PD (2010) Mycobacterium bovis at the animal human interface: A problem, or not? Vet Microbiol 140: 371-381. Link: http://bit.ly/2U8Uq2b

2. Malama S, Muma JB, Olea-Popelka F, Mbulo G (2013) Isolation of Mycobacterium Bovis from Human Sputum in Zambia: Public Health and Diagnostic Significance. J Infect Dis Ther 1: 3. Link: http://bit.ly/2RC4fUy
3. Smith NH, Gordon SV, dela Rua-Domenech R, Clifton-Hadley RS Hewinson RG (2006) Bottlenecks and broomsticks: the molecular evolution of Mycobacterium bovis. Nat Rev Microbiol 4: 670-681. Link: http://bit.ly/20cOGRb

4. Pal M (2007) Zoonoses. $2^{\text {nd }}$ ed. Satyam publishers, Jaipur, India. 124-125.

5. O'Reilly LM, Daborn CJ (1995) The epidemiology of Mycobacterium bovis infections in animals and man. A review. Tubercle Lung Disease 76: 1-46. Link: http://bit.ly/3aQUHfT

6. OIE Manual of Standards for Diagnostic Tests and Vaccines (2008) Bovine Tuberculosis Paris 683-697.

7. Olmstead AL, Rhode PW (2004) The Tuberculous Cattle Trust. Disease Contagion in an Era of Regulatory Uncertainty. J Econ Hist 64: 929-963. Link: http://bit.ly/2S1mulh

8. WHO (2006) The Global Plan to Stop TB, 2006-2015. Actions for lifetowards a world free of tuberculosis. Int J Tuberc Lung Dis 10: 240-241. Link: http://bit.ly/208IERC

9. Ameni G, Tadesse K, Hailu E, Deresse Y, Medhin G, et al. (2010) Transmission of Mycobacterium tuberculosis between farmers and cattle in central Ethiopia. PLos one 8: e76891. Link: http://bit.ly/37EDpRp

10. Cosivi O, Grange JM, Daborn CJ, Raviglione MC, Fujikura T, et al. (1998) Zoonotic tuberculosis due to Mycobacterium bovis in developing countries. Emerg Infect Dis 4: 59-70. Link: http://bit.ly/315smOw

11. Zinsstag J, Schelling E, Roth F, Kazwala RR (2006) Economics of bovine tuberculosis. In Thoen, C.O., Steele, J.H., Gilsdorf, M.J., ds. Mycobacterium bovis Infection in Animals and Humans Blackwell Publishing. Link: http://bit.ly/2ul5pEY

12. Office International des Epizooties (OIE) (2017) Roadmap for zoonotic tuberculosis. World Health Organization (WHO), Food and Agriculture Organization of the United Nations (FAO) and World Organisation for Anima Health. Link: http://bit.ly/2u0OTQk

13. Shitaye JE, Tsegaye W, Pavlik I (2007) Bovine tuberculosis infection in anima and human populations in Ethiopia: A review. Vet Med 8: 317-332. Link: http://bit.ly/2u67Dhx

14. Demelash B, Inangolet F, Oloya J, Asseged B, Badaso M, et al. (2009) Prevalence of bovine tuberculosis in Ethiopian slaughter cattle based on post-mortem examination. Trop Anim Health Prod 41: 755-765. Link: http://bit.ly/37Frpir

15. Regassa A, Tassew A, Amenu K, Megersa B, Abuna F, et al. (2010) Across sectional study on bovine tuberculosis in Hawassa town and its surroundings, Southern Ethiopia. Trop Anim Health Prod 42: 915-920. Link: http://bit.ly/3170cB9

16. Berg S, Schelling E, Hailu E, Firdessa R, Gumi B, et al. (2015) Investigation of the high rates of extra pulmonary tuberculosis in Ethiopia reveals no single driving factor and minimal evidence for zoonotic transmission of Mycobacterium bovis infection. BMC Infect Dis 15: 112. Link: http://bit.ly/3170Pum

17. Nuru A, Mamo G, Teshome L, Zewdie A, Medhin G, et al. (2015) Bovine tuberculosis and its risk factors among dairy cattle herds in and around Bahirdar City, Northwest Ethiopia. Ethiopian Vet J 19: 27-40. Link: http://bit.ly/2u1Y2bt

18. Dinka H, Duressa A (2011) Prevalence of bovine tuberculosis in Arsi Zones of Oromia, Ethiopia. African Journal of Agricultural Research 6: 3853-3858. Link: Link: http://bit.ly/2GEBBeY

19. Ameni G, Aseffa A, Engers H, Young D, Gordon S, et al. (2007) High Prevalence and Increased Severity of Pathology of Bovine Tuberculosis in Holsteins Compared to Zebu Breeds under Field Cattle Husbandry in Central Ethiopia. Clin Vaccine Immunol 14: 1356-1361. Link: http://bit.ly/2RGasyA 
20. Tschopp R, Schelling E, Hattendorf J, Young D, Aseffa A, et al. (2010) Repeated cross-sectional skin testing for bovine tuberculosis in cattle kept in a traditional husbandry system in Ethiopia. Vet Rec 167: 250-256. Link: http://bit.ly/315uJko

21. Office International des Epizooties (OIE ) (2008) Manual of Standards for Diagnostic Tests and Vaccines. Bovine Tuberculosis. Paris 683-697.

22. Thrusfield M (2005) Veterinary Epidemiology. $2^{\text {nd }}$ Edition, Blackwell Science Ltd., United Kingdom.

23. Pace JE, Wakeman DL (2003) Determining the age of cattle by their teeth. In I. E. C. University of Florida (Ed.)

24. Nicholson MJ, Butterworth MH (1986) A guide to condition scoring of zebu cattle, Addis Ababa, Ethiopia. International Livestock Centre for Africa. Link: http://bit.ly/316Ukt4

25. STATA version 12. Statistics data analysis. Statacorp, 4905 Lakeway Drive College Station, Texas 77845 USA.

26. Tamiru F, Hailemariam M, Terfa W (2013) Preliminary study on prevalence of bovine tuberculosis in cattle owned by tuberculosis positive and negative farmers and assessment of zoonotic awareness in Ambo and
Toke Kutaye districts. Ethiopia. J Vet Med Anim Health 5: 288-295. Link: http://bit.ly/37G7aRK

27. Girmay G, Pal M, Deneke Y, Weldesilasse G, Equar Y (2012) Prevalence and Public Health Importance of Bovine Tuberculosis in and Around Mekelle Town, Ethiopia. Int J Livest Res 2: 180-188. Link: http://bit.ly/37G7xvC

28. Pritchard DG (1988) A century of bovine tuberculosis 1888-1988: Conquest and Controversy. J Comp Pathol 99: 357-399. Link: http://bit.ly/3b4IEgq

29. Sinha RN (1994) Mycobacterium bovis. In The Significance of Pathogenic Microorganisms in Raw Milk 141: 166

30. Bolske GL, Englund H, Wahlstrom GW, de Lisle DM, Collins PS, et al. (2010) Tuberculosis (In Pierre-Charles Lefe'vre, Jean Blancou, Rene' Chermette, Gerrit Vilenberg eds). Infectious and Parasitic Diseases of livestock. 2: 10751096.

31. Barlow AM, Mitchell KA, Visram KH (1999) Bovine tuberculosis in llama (Lama glama) in the UK. Vet Rec145: 639-640. Link: http://bit.ly/2u0SKNi

32. Admassu B, Kebede E, Shite A (2015) Review on Bovine Tuberculosis. Eur J Biol Sci 7: 169-185 Link: http://bit.ly/36E5NBB
Discover a bigger Impact and Visibility of your article publication with Peertechz Publications

Copyright: (C) 2020 Lemu D, et al. This is an open-access article distributed under the terms of the Creative Commons Attribution License, which permits unrestricted use, distribution, and reproduction in any medium, provided the original author and source are credited. 